\title{
Republikańska koncepcja rządów prawa, czyli co historyk idei może dać filozofowi
}

I. Historia idei to zaprawdę dyscyplina fascynująca i jednocześnie niedookreślona. Niedookreśloność to jej siła. Ta niedookreśloność historii idei politycznych i prawnych odzwierciedla się już w różnych nazwach przyjętych przez dyscyplinę: czy to $\mathrm{w}$ nielubianej przeze mnie historii doktryn polityczno-prawnych czy historii teorii politycznych, historii filozofii prawa i filozofii politycznej, czy po prostu historii myśli politycznej i prawnej. Obstaję przy historii idei jako najbliższej jej desygnatowi. W końcu badacze zajmują się badaniem myśli ludzkiej, myśli poświęconej polityce i prawu, dwom najistotniejszym zjawiskom związanym z życiem zbiorowym.

Na każdej konferencji poświęconej historii idei politycznych i prawnych, czy to w Polsce czy za granicami, zawsze uderzała i nadal uderza mnie podwójna struktura prowadzonego tam dyskursu. $Z$ jednej strony funkcjonują badacze, artykułujący teksty, które są bardziej abstrakcyjne i uniwersalne i pomimo zastosowanej metody diachronicznej jednak są bliższe podejściu filozoficznemu, a więc nadawaniu nowego znaczenia terminom, ideom i myśli twórców sprzed wieków. W pewnym stopniu popełniają oni grzech ahistoryzmu, wychodząc z teraźniejszości i próbując odczytać stare idee z punktu widzenia doświadczeń współczesności.

Drugie podejście kładzie nacisk na historyczny kontekst i detal. Bardzo często wyklucza to możliwość prowadzenia dyskusji, bo na jakiekolwiek pytanie otrzymujemy odpowiedź, że źródła historyczne mówią to, a przecież dobrze wiemy, że zreferowane same nic nie mówią, są jedynie medium, które trzeba poddać obróbce intelektualnej i, stosując metody hermeneutyczne, odczytać ich znaczenie. Nie chcę w tym miejscu wchodzić w kwestie metodologiczne, które kiedyś mnie tak fascynowały, ale twierdzę, że uznając koniecz-

\footnotetext{
* Tekst jest referatem drukowanym równolegle w materiałach konferencji historyków doktryn politycznych i prawnych, odbytej w 2012 r. w Szklarskiej Porębie. Redakcja dziękuje organizatorom konferencji za udostępnienie tekstu referatu.
} 
ność pewnego rygoryzmu metodologicznego, jednocześnie jestem daleki od swoistego terroryzmu na tym polu, charakteryzującego polską jurysprudencję.

Po zarysowaniu obserwowanej sytuacji chcę zabrać glos w obronie dyscypliny i bronić miejsca historii idei w jurysprudencji, jak i bronić prostej i wręcz banalnej tezy, że historia idei musi być uprawiana jako nauka łącząca kompetencje filozoficzne z historycznymi. Celem jest zasypanie rowu dzielącego badaczy bliższych historii bezprzymiotnikowej i badaczy bliższych podejściu, nazwijmy to, filozoficznemu. Jak ująłem to w tytule, historyk idei może dać i to bardzo dużo filozofowi prawa. Celem tekstu jest obrona tezy, że abstrakcyjne, ponadczasowe, ahistoryczne podejście do teorii i filozofii prawa jest naukową patologią, która powinna ulec eliminacji. Teoretycy i filozofowie prawa podchodzący z wyższością do historycznie zorientowanej jurysprudencji odrzucają wiedzę i często wyważają otwarte drzwi.

Friedrich Nietsche podkreślał, że podejście do przeszłości powinno być dokonywane w ,służbie życia”, a więc ani nie antykwaryczne, ani nie gloryfikujące przeszłość, ale łączące przeszłość z teraźniejszością ${ }^{1}$. Łatwo powiedzieć, ale jak to zrobić? Inny znany socjolog francuski, który zajmował się pamięcią zbiorową, Eric Halbswach, napisal, że historia to cmentarzysko idei, a jednocześnie wskazywał, że pamięć zbiorowa opiera się na niektórych z tych idei i twórczo je przekształca i wykorzystuje ${ }^{2}$. Metafora Halbswacha jest niezwykle użyteczna, bo niejako pokazuje połączenie, sugerowane przez Nietschego odnośnie do „historii w służbie życia” a więc przeszłości i teraźniejszości. To również sugestia dotycząca konieczności współpracy historyków idei i filozofów polityki i prawa.

W naszej dyscyplinie mamy świadectwa instytucjonalne takiej współpracy, by wspomnieć History of Ideas Unit, założony i kierowany przez Eugena Kamenkę na Australian National University w ramach Research School for Social Sciences. To w tej jednostce powstały świetne prace na temat idei biurokracji, prawa natury, rządów prawa, by wymienić tylko najważniejsze. Niestety, History of Ideas Unit zakończył swoje życie wraz ze śmiercią założyciela, ale współpraca historyków idei z filozofami jest tam kontynuowana. Inny przykładem jest Cambridge School in the History of Ideas, a w szczególności prace Quentina Skinnera i jego prace nad wczesnonowożytną myślą angielską. W Polsce mieliśmy Warszawską Szkołę Historii Idei z Andrzejem Walickim i Jerzym Szackim, jako głównymi jej przedstawicielami, w której również stosowano metodę łączenia podejścia historycznego z kompetencją filozoficzną.

Po tym krótkim wstępie dotyczącym wyjaśnienia, czas przejść do meritum. W poniższym tekście używam idei republikańskiej koncepcji rządów

${ }^{1}$ W.F. Nietzsche, Untimely Meditations, Cambridge University Press, 1997, s. 47.

${ }^{2}$ M. Halbwachs, On Collective Memory, Chicago: University of Chicago Press 1992. 
prawa jako empirycznego przykładu skomplikowanego charakter historii idei i użyteczności historii idei dla teoretycznej refleksji nad prawem.

To, co mnie interesuje od lat, to kwestia rządów prawa. Temat jest niezwykle skomplikowany, o długiej historii i uczeni do dziś spierają się, czy rule of law jest tym samym co Rechtsstaat. Historia idei rządów prawa jest szczególna, ponieważ sama idea rządów prawa w przeciwieństwie do rządów człowieka, a więc rządów opartych na przewidywalności, jest stara, ale w naukach prawnych została wyrażona w Wielkiej Brytanii przez A.V. Dicey'a w bardzo prowincjonalny sposób. Otóż uważał on, że w Anglii panują rządy prawa (rule of law), ponieważ nie ma sądownictwa administracyjnego, które istniało we Francji po drugiej stronie tego, co Brytyjczycy nazywają English Channel, a co Europejczycy znają jako Kanał La Manche. Nikt się nie spodziewał, że idea ta zrobi tak wielką karierę ${ }^{3}$. W kontynentalnej Europie karierę zrobiła idea państwa prawnego (Rechtsstaat). Dla uproszczenia można powiedzieć z niewielkim marginesem błędu, że idea państwa prawa związana była z procesem budowania państwa w kontynentalnej części Europy. O ile brytyjskie rule of law nie wskazuje na państwo i jego instytucje, ale mówi właśnie o prawie, jako tym, co panuje i ogranicza władzę, to myślę, że koncepcja państwa prawnego zrobiła karierę polityczną wraz ze zjednoczeniem Niemiec i obietnicą polityczną, że w Rzeszy nikt nie straci, bo państwo będzie podlegało prawu. Różnica między brytyjską koncepcją rządów prawa a niemiecką ideą państwa prawa to różnica miedzy państwem nowożytnym w wersji niemieckiej i organizacją polityczną w Zjednoczonym Królestwie, które do dzisiaj nie przeszło przez okres państwa nowożytnego z centralizmem instytucji, hierarchiczną strukturą organów, połączonym z tym prawnym wyrażaniem idei państwa jak w niemieckiej filozofii prawa II połowy XIX w. W myśli politycznej wyspiarzy do dzisiaj istnieje problem z koncepcją państwa zwącego się governement, Commonwealth, Crown.

Wydaje mi się, że różnice pięknie oddał Max Weber w swej konceptualizacji typów idealnych racjonalności i jej przejawów w prawie i legitymizacji władzy:

1. Formalnej racjonalności prawa i formalnym modelu legitymizacji władzy z naciskiem na tworzenie prawa (lawmaking), a nie odnajdywanie prawa (lawfinding). Historycy myśli socjologicznej wskazują, że właśnie Weber opisał stan jurysprudencji czy Allgemeine Staatslehre w Niemczech na początku XX w.

2. Z kolei, jak dobrze wiemy, Weber miał niesłychany problem z Anglią, bo to niby jedno z pierwszych państw kapitalistycznych, a więc takich, które powinny przyjąć model prawa formalnie racjonalnego zapewniającego prze-

${ }^{3}$ A. Richard Cosgrove, The Rule of Law: Albert Venn Dicey, Victorian jurist. London: Macmillan, 1980, s. xv, 319. 
widywalność. A jednak nic z tego, bo prawo w Anglii nie odpowiada modelowi racjonalności formalnej, a bardziej racjonalności materialnej, oraz nawet jest irracjonalne, zaś model legitymizacji władzy najbardziej odpowiada modelowi legitymizacji opartej na tradycji.

Wszystko to należy powiedzieć, aby pokazać, że thumaczenie pojęć wiąże się z syndromem „lost in translation”. Ale tak wcale być nie musi. Nasza dyscyplina - historia idei - ma tu duże pole do działania.

W okresie, kiedy angielski stal się lingua franca współczesnego świata, pojęcie rządów prawa (rule of law) dominuje w ramach nauk prawnych, ale nie tylko.

Otóż od dłuższego czasu, mniej więcej od początków XXI w., idea rządów prawa zastąpiła ideę demokracji. Dyskurs rządów prawa dominuje w skali globalnej w takim samym stopniu jak prawa człowieka dominowały w latach 70. i 80. XX w. Warto więc zrekonstruować zarówno przyczyny jak i sposób rozumienia rządów prawa w tym dyskursie. Aby to zrozumieć, należy chyba zacząć od tzw. Trzeciej Fali demokratyzacji w Europie Południowej: Grecji, Hiszpanii i Portugalii - kiedy to stare reżimy czarnych pułkowników, reżim generała Franco i reżim Salazara zostały zastąpione przez demokracje w wymienionych trzech krajach. Niedługo potem nastąpiła fala demokratyzacji w wybranych krajach Ameryki Południowej. Wydawało się, że demokracja jest lekarstwem na zło tego świata oraz że reżim demokratyczny zapewni poprawę sytuacji ekonomicznej. Tak się jednak nie stało i po złych doświadczeniach i poszczególni myśliciele jak i potężne instytucje międzynarodowe, takie jak World Bank i International Monetary Fund - a więc instytucje narzucające określone strategie polityki fiskalnej i ekonomicznej - przyjęły rządy prawa jako trzon dyskursu.

Rządy prawa rozumiane są w sposób prosty, a więc jako system instytucjonalnych zabezpieczeń przed arbitralnością władzy politycznej. Można powiedzieć, że jest to ścisłe, by wręcz powiedzieć, że klasyczne podejście liberalne bliższe wydaje się Hayekowi niż wysublimowanym rozumowaniom filozofów prawa, takim jak np. Joseph Raz, nad cechami rządów prawa. Nietrudno też zauważyć, że poprawie dyskursu rządów prawa sprzyjało i zbiegło się w czasie $\mathrm{z}$ dokończeniem budowy globalnego reżimu ekonomicznego, czegoś w rodzaju ekonomicznej konstytucji świata. Sposób rozumienia rządów prawa jest właściwie taki sam jak w ORDO-liberalismus czy propagowany przez Mont Pellerin Society, a więc system instytucjonalnych amortyzatorów chroniących instytucje ekonomiczne przed presją polityki.

W dominującym dyskursie liberalna koncepcja rządów prawa jest przedstawiana jako jedyna i uniwersalna. Można mieć poważne wątpliwości, czy jest ona jedyna, bo istnieje wiele różnych koncepcji rządów prawa, poza liberalną. Nie ma ona też charakteru uniwersalnego. To nieprawda, że można zaadaptować liberalne koncepcje rządów prawa do każdego systemu społecz- 
nego. Ładnie przedstawił to wiele lat temu charyzmatyczny prawnik z Uniwersytetu Harvarda Roberto Mungabeira Unger w pracy Law in Modern Society $^{4}$. Wskazał on $\mathrm{w}$ niej na specyficzny system organizacji społeczeństwa oraz aksjologii tegoż społeczeństwa, generujący autonomiczność system prawny, a więc liberalny system organizacji społeczeństwa wygenerował system prawny określany przez Ungera „rządami prawa”.

Powstaje jednak pytanie, czy rzeczywiście mamy tylko jeden model rządów prawa $\mathrm{i}$ jest to model liberalny? Czy może istnieje alternatywny model rządów prawa?

W liberalnej charakterystyce rządów prawa podkreśla się, że rządy prawa zapobiegają arbitralności władzy. Wydaje mi się, że trzeba bliżej przeanalizować ten wątek arbitralności. Rządy prawa to nie rządy sprawowane przez prawo, czyli poza zapobieganiem arbitralności musi tam wchodzić jeszcze jakiś inny istotny element związany z cechą prawa, które ma rządzić. Nie ma mowy o rządach dobrego prawa a jedynie o rządach prawa.

II. Wolność jako autonomia. Punktem wyjścia dla rozważania arbitralności władzy jest kwestia wolności. To w celu zapewnienia wolności mówi się o rządach prawa. Liberalizm, jak wiemy, pojmuje wolność jako wolność negatywną, by użyć typologii I. Berlina - wolność „od czego”. Jest to wolność rozumiana jako sfera autonomii jednostki, w którą nikt i nic nie powinno ingerować. Rozwój takiej koncepcji wolności związany był, jak to napisał wybitny kanadyjski filozof Charles Taylor z „odkrywaniem siebie”, czyli powolnym podrywaniem odrębności i autonomii jednostki ${ }^{5}$. W liberalnej filozofii politycznej koncepcja wolności negatywnej powiązana jest z filozofią moralną i rozwojem uniwersalizmu w myśli etycznej. Przedstawił to w swoich wykładach z etyki inny wybitny współczesny liberalny filozof polityczny - John Rawls ${ }^{6}$. Jednostka ludzka staje się autonomicznym podmiotem moralnym, który sam wie, co jest słuszne czynić, jak postępować w życiu, kierując się ,rozumem praktycznym”. Jednostka sama wie, co jest słuszne i jak dobrze żyć. Idea ta najpełniej została rozwinięta w filozofii Immanuela Kanta i przejęta później do filozofii politycznej liberalizmu oraz do filozofii prawa opartej na wartościach liberalnych. $Z$ członków panteonu liberalizmu najładniej oddał ją na gruncie filozofii społecznej i politycznej John Stuart Mill, formułując tzw. non-harm principle ${ }^{7}$. Mill na pytanie, jak daleko się-

${ }^{4}$ R.M. Unger, Law in Modern Society, Free Press, 1977.

${ }^{5}$ C. Taylor, Sources of the Self. Making of Modern Identity, Harvard University Press, Cambridge MA, 1989.

${ }^{6}$ J. Rawls, Lectures on the history of moral philosophy, Harvard University Press, Cambridge MA, 1999 oraz idem, Lectures on the History of Political Philosophy, Harvard University Press, Cambridge MA, 2007.

${ }^{7}$ J.S. Mill, Utylitaryzm. O wolności, Warszawa 2006. 
gają granice wolności jednostki, odpowiedział, że tak daleko, dopóki jednostka swoim działaniem nie szkodzi innym. W ten sposób doprecyzował sferę autonomii jednostki, zdając sobie sprawę, że diabeł tkwi w szczegółach i że dokładnie nie wiadomo, co to znaczy „nie szkodzić innym” oraz co rozumieć przez „działanie”: czy tylko pewne zachowania czy też akty mowy. Na marginesie dodam, że zasada Milla do dziś stanowi twardą podstawę orzeczeń sądów w krajach liberalno-demokratycznych. Stała się też zasadą, na której opierają się rozważania dotyczące katalogu praw człowieka w tychże demokracjach liberalnych. Można powiedzieć, że zasada wolności rozumianej jako sfera autonomii jednostki i granice tej wolności rozumiane w oparciu o nonharm principle są osią rozumienia rządów prawa we współczesnym świecie zdominowanym przez ideologię liberalizmu.

III. Wolność republikańska i rządy prawa. We współczesnym spektrum filozofii politycznej nurt, który jest przeciwstawny liberalizmowi, pomimo tego, że często jest mylony z liberalizmem, to nurt myśli republikańskiej (civic republicanism). W słynnej i do dziś ciągnącej się debacie między liberałami a komunitarystami przedstawiciele republikanizmu zajmowali i zajmują swoiste stanowisko, coś w rodzaju trzeciej drogi. Koncepcja wolności w ramach republikanizmu została filozoficznie przedstawiona przez Philipa Pettita, australijskiego badacza, który większość swojej kariery badawczej spędził w Research School for Social Sciences w Australian National University w Canberze, a obecnie pracuje w Uniwersytecie w Princeton. Philip Pettit w swojej słynnej pracy Republicanism. A Theory of Freedom and Government ${ }^{8}$ przedstawił rozbudowaną koncepcję wolności rozumianą jako brak dominacji, a nie jako sferę autonomii. Zanim przejdę do porównania dwóch koncepcji wolności, chcę dodać kilka kwestii.

Przed Pettitem Hannah Arendt, rekonstruując starożytną grecką polis, wskazywała na to, co B. Constant nazywał „wolnością starożytnych” rozumianą jako wolność partycypacji w sferze publicznej Co więcej, Arendt podkreślała, że wolność w świecie starożytnym nie istniała w sferze prywatnej, ponieważ ta oparta była na istnieniu hierarchii związanych z koniecznością reprodukcji życia biologicznego.

Kwestia druga: republikańska koncepcja wolności sformułowana współcześnie przez P. Pettita nie jest tylko ideą zamkniętą w wieży z kości słoniowej, ale stanowi podstawę najpierw do rozwoju pewnych technik postępowania w kryminologii (zobacz prace J. Braithwaite i P. Pettita ${ }^{9}$ ), a także

${ }^{8}$ P. Pettit, Republicanism: A Theory of Freedom and Government, Oxford University Press, Oxford 1997.

${ }^{9}$ Zob. J. Braithwaite, P. Pettit, Not just desert. A Republican Theory of Criminal Justice, Oxford University Press, Oxford 1992. 
wcielanego w życie programu politycznego P. Zapatero w okresie sprawowania władzy przez jego partię w Hiszpanii ${ }^{10}$.

Wolność według Pettita to brak dominacji. Dwie sprawy wiążą się z tak pojętą wolnością:

1. Sprawa eliminacji źródeł dominacji.

2. Sprawa arbitralności władzy jako przyczyna dominacji.

W republikańskiej koncepcji wolności ważna jest relacja podmiotu W stosunku do innych podmiotów. Istotę stanowi nie arbitralną ingerencję w wybory dokonane przez jednostkę. Wydaje się, że dominacja występuje wtedy, kiedy podmiot zewnętrzny wpływa arbitralnie na wybory dokonywane przez jednostkę. Wpływanie na wybory jednostki nie jest arbitralne, kiedy „track people's avawed or readily avowable interest”" Wolność w rozumieniu republikańskim różni się od wolności liberalnej w dwóch istotnych punktach:

1. Nieinterwencja w sferę autonomii nie jest wystarczającą gwarancją wolności, jeżeli inne podmioty posiadają wystarczającą władzę, aby wpływać arbitralnie na wybory danej jednostki.

2. Nieinterwencja jest niekonieczną przesłanką wolności, jeżeli taka interwencja jest niearbitralna.

Christian List z London School of Economics słusznie napisał, że liberalna koncepcja wolności odnosi się do faktycznego wpływania na sferę autonomii i wybory dokonywane przez jednostkę, podczas kiedy republikańska koncepcja wolności określa wolność jako brak dominacji i koncentruje się nie tylko na faktycznych ingerencjach arbitralnych, ale również na ingerencjach potencjalnych, która może, ale nie musi wystąpić. Najlepiej to pokazać na przykładzie trzech hipotetycznych sytuacji:

1. Jarek jest niewolnikiem w społeczeństwie opartym na akceptowalności instytucji niewolnictwa i jego właściciel Donald źle go traktuje. Można powiedzieć, że w tym przypadku właściciel podejmuje wybory, nie biorąc pod uwagę preferencji Jarka.

2. Jarek jest niewolnikiem w społeczeństwie akceptującym instytucję niewolnictwa, ale jego właściciel Donald bardzo dobrze go traktuje i Jarek jest w stanie dokonywać wyborów między dobrami $x$ i $z$. Jego właściciel postanowił nie ingerować w sferę wyborów Jarka.

3. Jarek jest obywatelem liberalnego kraju z szerokim zakresem praw i wolności obywatelskich. Jarek jest w stanie dokonywać wyborów między dobrem $x$ i $z$ i nikt nie ingeruje w jego wybór.

${ }^{10}$ Zob. J.L. Marti, P. Pettit, A Political Philosophy in Public Life. Civic Republicanism in Zapatero's Spain, Princeton University Press, Princeton, New Jersey 2010.

${ }^{11}$ P. Pettit, Deliberative Democracy, the Discursive Dilemma, and Republican Theory, w: Debating Deliberative Democracy, red. J.S. Fiskin, P. Laslett, Oxford: Blackwell, 2003, s. 151. 
Przeanalizujmy teraz, w jakich sytuacjach Jarek jest w stanie dokonywać wyboru, a więc cieszy się wolnością. Wszyscy się zgodzą z opinią, że Jarek nie cieszy się wolnością w sytuacji 1. i że cieszy się wolnością w sytuacji 3.

W sytuacji 1. Jarek doświadcza zarówno ingerencji w sferę wyboru jak i dominacji i dlatego jest pozbawiony wolności w sensie liberalnym i republikańskim. W sytuacji 3. Jarek jest wolny i od dominacji, i od ingerencji w sferę autonomicznego wyboru, więc jest wolny i w sensie wolności liberalnej, jak i wolności republikańskiej.

Sytuacja 2. jest jednak bardziej skomplikowana, ponieważ Jarek faktycznie nie jest ograniczony w sferze swoich wyborów. Zgodnie z tradycja liberalną brak ograniczenia w sferze wyborów oznacza wolność, a więc Jarek w sytuacji 2. pomimo faktu, iż nadal jest niewolnikiem, jest człowiekiem wolnym w sensie liberalnym, ponieważ nikt nie ingeruje w sferę jego autonomicznych wyborów. Jednocześnie w sytuacji 2. Jarek jest potencjalnie narażony na wpływanie na jego wybory w sposób arbitralny i funkcjonuje w sytuacji dominacji, a więc według tradycji republikańskiej nie jest osobą wolną ${ }^{12}$.

Na podstawie powyższych przykładów widać wyraźnie, że przedstawiciele liberalizmu i republikanizmu odmiennie pojmują wolność i jej ograniczenia. Kryteria klasyfikacji sytuacji jako wolności i braku wolności nie przebiega tak samo w dwóch wielkich filozofiach politycznych, choć obie odwołują się do wolności, równości, rządów prawa, sprawiedliwości i własności, bardzo często były też i są mylone z sobą. Odchodząc na chwilę od wolności, można powiedzieć, że republikańska koncepcja własności ma charakter etyczny i właściwie sprowadza się do własności nieruchomości (real property) ${ }^{13}$, a zwolennicy liberalizmu w epoce wczesnonowożytnej mieli problem z własnością ruchomą (mobile property), taką jak pieniądze czy akcje w spółkach.

Najważniejszy jednak jest fakt, że republikańska koncepcja wolności jako braku dominacji faktycznej jak i potencjalnej, a więc w sferze uregulowań i instytucji prawnych, wskazuje, że republikanie wiązali i wiążą ze sobą kwestie wolności i rządów prawa, które mają zapewnić wyeliminowanie dominacji. Wolność republikańska to wolność poprzez prawo, a nie jedynie wolność autonomii. To z kolei prowadzi nas do odmiennego pojmowania rządów prawa i samego prawa $\mathrm{w}$ dwóch wielkich filozofiach politycznych: liberalizmie i republikanizmie.

${ }^{12}$ C. List, Republican freedom and the rule of law, „Politics, Philosophy and Economics”, nr 5, 2005, s. 209-210.

${ }^{13}$ Ciekawe, że konfuzja z republikańską i liberalną koncepcją własności i używania praw własności widoczna jest w W. Blackstone'a, Commentaries on the Laws of England, University of Chicago Press, Chicago 1979. Nawet John Locke, ojciec liberalizmu politycznego, pisząc o podstawach legitymizacji własności, odwoływał się do argumentów republikańskich. Zobacz J. Waldron, God, Locke and Equality. Christian Foundations of John Locke's Political Thought, Cambridge University Press, Cambridge, UK 2002. 
Wychodząc z odmiennych koncepcji wolności, można hipotetycznie rozważać, że republikańska koncepcja wolności zakłada rządy prawa eliminujące arbitralność decyzji władzy. Wyobraźmy sobie hipotetycznie dwa kraje:

A. Kraj dyktatorski, ale z dyktatorem bardzo łagodnym pozwalającym obywatelom na zachowanie autonomii i nieingerującym w ich decyzje.

B. Kraj drugi to kraj demokratyczny z rządami konstytucyjnymi.

W kraju A wolność w sensie liberalnym istnieje jako wolność wyboru, ale jest to wybór z dobrej woli i łaski dyktatora, który w każdym momencie może zmienić swoją decyzję. W kraju B wolność jest zagwarantowana przez prawo i prawo eliminuje możliwość arbitralności i dominacji nad obywatelami. Myślę, ze przykłady dotyczące odmiennej koncepcji prawa i rządów prawa w liberalizmie i republikanizmie zostały w wystarczający sposób udokumentowane. Republikańska wersja prawa kładzie nacisk na jakość prawa w celu zapewnienia wolności jako braku dominacji. Jakość, a więc pewne cechy prawa, które gwarantować będą wyeliminowanie arbitralności i dominacji.

Podczas gdy przedstawiciele liberalizmu politycznego kładą nacisk na zakres wolności indywidualnej, zwolennicy republikańskiej filozofii politycznej koncentrują się na tym, jak dalece trwałe i jak liczne są instytucje prawne gwarantujące brak dominacji i arbitralności władzy. Stąd już tylko mały krok w kierunku rozważań nad źródłami takiego systemu prawnego i jego powiazań z polityką i z aktywnością obywateli.

Liberałowie w swojej filozofii politycznej proponują system, w którym prawo ma być gwarantem wolności jednostki rozumianej jako autonomia. W efekcie proponują system instytucji prawnych, które niejako dominują nad polityką. Chyba doskonałym przykładem jest Teoria sprawiedliwości Johna Rawlsa $^{14}$ - wyraźnie widać tu, że uzasadnienie dla instytucji prawnych ma charakter oderwany od codziennej polityki. Codzienna polityka ma się toczyć w ramach prawnych już istniejących. Stąd tak częste u liberałów przeciwstawianie polityki konstytucyjnej polityce normalnej.

Max Weber analizował skutki dominacji prawa nad polityką, twierdząc, że oznaczają one utratę legitymizacji (moralnej) przez prawo oraz stymulowanie konfliktogennej roli prawa. Innymi słowy, gdy prawo odgrywa w życiu społeczno-politycznym rolę dominującą, to obywatele zamiast argumentować w obronie swoich wartości i próbować osiągnąć kompromis, udają się do sądu. Tego rodzaju zjawisko prowadzi w krótkim okresie do wzrostu anomii społecznej.

Kwestia relacji między prawem a polityką ujmowana jest odrobinę odmiennie w nurcie konserwatywnym myśli liberalnej od nurtu bardziej zorientowanego na sprawiedliwość społeczną. We współczesnym świecie konsty-

${ }^{14}$ J. Rawls, Teoria sprawiedliwości, PWN Warszawa, 2010. 
tucyjnych liberalnych demokracji te dwa podejścia wyznaczają normatywne ramy dla praktyki politycznej.

W podejściu konserwatywnym rola prawa jest ograniczona, a za główny cele sądów uznaje się administrowanie sprawiedliwością rozumianą przede wszystkim jako sprawiedliwość redystrybutywna, związana z prawem karnym. Prawo ma działać tak, aby zapewnić ład i porządek społeczny oraz polityczny. Sędziowie nie powinni wychodzić poza literalną wykładnię prawa.

Według liberałów prawo nie sprowadza się do litery prawa; przypisują mu oni większą rolę. Podkreślają, jak na przykład Ronald Dworkin, że sędziowie odgrywają szczególną rolę i że w prawie jest miejsce na kreatywną działalność sądów i sędziów. Dostrzegają oni, że prawo pełni funkcje edukacyjne, co stanowi podstawę solidarności społecznej, jak nauczał stary, ale zacny Emil Durkheim. Prawo w koncepcjach liberalnych pełni w życiu społecznym i politycznym funkcje włączające, a nie wykluczające czy ograniczające. Wszelkie ograniczenia prawne muszą podlegać uzasadnieniu i to uzasadnieniu o charakterze uniwersalnym. W życiu społecznym i politycznym prawo pełni funkcje komunikacyjne, edukacyjne i symboliczno-ekspresyjne. Jednak nawet przy tak szerokim ujęciu funkcji i roli prawa należy podkreślić, że prawo ma swoje ograniczenia i nie nadaje się do spełniania funkcji przynależnych światu polityki, chociaż we współczesnym świecie taką rolę mu się przypisuje.

W myśleniu opartym na założeniu dominacji prawa nad polityką można zauważyć dwa aspekty określające ten sposób rozumowania. Pierwsze to założenie, że sfera normatywna, a w szczególności normatywność o charakterze publicznym, jest zasadniczo wewnętrzną sprawą prawa. Zgodnie z takim rozumowaniem polityka pojmowana jest jako poszukiwanie najlepszego kompromisu między rywalizującymi interesami. Tak więc wartości leżą poza światem polityki, w naszym wypadku lokują się w sferze prawa, skoro polityka to brudna sfera gry interesów. Takie podejście do polityki zakłada zubożone pojęcie moralności publicznej. Już Judith Shklar pokazała, jak zubożona jest koncepcja moralności zredukowana do modelu legalistycznego ${ }^{15}$.

W przeciwieństwie do liberalizmu politycznego, republikanizm zakłada odmienną relację między prawem a polityką. To deliberacja polityczna dostarcza podstawy i legitymizację prawu. Republikanizm to filozofia polityczna, według której instytucje społeczne i prawne powinny być tak zaprojektowane, aby zapewnić wolność w sensie republikańskim, a więc wyeliminować dominację nad obywatelami. Teoria republikańska zajmuje się nie tylko analizą idei i pojęć, ale także analizuje instytucje i politykę w najlepszym stopniu zapewniającym pożądany normatywnie wynik. Republikańscy teoretycy

${ }^{15}$ Judith N. Shklar, Legalism: Law, Morals and Political Trials, Cambridge 1986. Podaje ona następującą definicję legalizmu: jest to ,the ethical attitude that holds moral conduct to be a matter of rule following, and moral relationships consists of duties and rights determined by rules", s. 1 . 
i filozofowie polityczni propagują i bronią deliberowanego i kolektywnego podejścia do procesu podejmowania decyzji, bronią decentralizacji władzy, równej wolności dla wszystkich obywateli, równości szans oraz podstawowego zabezpieczenia społecznego dla obywateli. Pomimo podobieństwa tych postulatów $\mathrm{z}$ hasłami ideologii liberalizmu politycznego argumenty używane przez zwolenników republikanizmu są odmienne i sprowadzają się do idei wolności jako braku dominacji.

IV. Co historyk idei może dać filozofowi prawa? Gdybyśmy pobawili się w coś, co M. Foucault ładnie nazywał ,archeologią wiedzy”, a więc w próbę zrekonstruowania idei, które zostały zapomniane i zastąpione w życiu politycznym i społecznym innymi ideami, to dowiemy się, że przed liberalizmem przynajmniej w niektórych kręgach kulturowych dominująca była inna koncepcja wolności, a mianowicie idea republikańska. To idee republikańskie żywe były w okresie wczesnonowożytnej Europy na terenie państw Półwyspu Apenińskiego, w Niderlandach, Polsce i w Anglii. Największe znaczenie dla teraźniejszości miało to, co działo się w świecie idei na terenie Anglii, jako że stała się ona później kolebką liberalizmu.

Współczesna filozofia polityczna republikanizmu nie byłaby możliwa bez prac historycznych Quentina Skinnera i jego badań nad myślą renesansowych Włoch jak i nad myślą polityczną we wczesnonowożytnej Anglii. To Quentin Skinner jako historyk idei zrobił chyba najwięcej dla przywrócenia wiedzy o republikanizmie epoki wczesnonowożytnej i ludzie związani z Cambridge School in the History of Ideas ${ }^{16}$, jak na przykład J.G.A. Pocock ${ }^{17}$, który przebadał związki między republikańską myślą w XVI-wiecznej Florencji, myślą polityczną w okresie wojny domowej w Anglii i myślą polityczną Rewolucji Amerykańskiej.

Tak się złożyło, że książka wielokrotnie wspominanego Philipa Pettita Republicanism ukazała się w tym samym roku co książka Quentina Skinnera Liberty before liberalism, a więc w 1998 roku. Obaj badacze współpracowali ze sobą, prowadząc seminarium z filozofii politycznej i historii idei w Research School for Social Sciences w Australian National University w Canberze i we wstępie składają sobie podziękowania. Można powiedzieć, że wygląda to jak przykład podwójnego wzmacniania, gdzie historyk dostaje wzmocnie-

${ }^{16}$ Zobacz w szczególności jego niewielką objętościowo, ale bardzo istotną pracę pt. Liberty before liberalism, Cambridge University Press 1998, w której zrekonstruował historyczną republikańską koncepcję wolności w myśli angielskiej, Cambridge University Press, Cambridge 1997, a także idem, Paradoxes of political liberty, Tanner Lectures on Human Values, Harvard University, 1984 oraz fundamentalne dzieło The Foundation of Modern Political Thought, 2 tomy, Cambridge University Press, Cambridge 1978 i Hobbes and republican liberty, Cambridge University Press 2008.

${ }^{17}$ J.G.A. Pocock, The Ancient Constitution and the Feudal Law, Cambridge University Press 1957 i The Machiavellian Moment, Princeton University Press, Princeton 1975. 
nie od filozofa, a filozof z kolei wzmacniany był solidną wiedzą z zakresu historii idei.

Podejście filozofów do problemów badawczych jest odmienne od podejścia historyków. Ci pierwsi koncentrują się na zjawiskach i ideach uniwersalnych i usiłują odkryć uniwersalne prawidłowości, zaś historycy idei dbają o detal i cechy szczególne danej idei w konkretnym okresie czasu. Opisana przeze mnie powyżej sytuacja z republikańską i liberalną koncepcją wolności wymagała na wstępie drobiazgowych prac historycznych, aby oddzielić warstwy dyskursu liberalnego od warstw dyskursu republikańskiego. W następnej kolejności filozof polityczny rozwinął zrekonstruowane idee we współczesny system filozofii politycznej. Opisany przykład badań nie tyle interdyscyplinarnych, ile transdyscyplinarnych wskazuje, że uprawianie naszej dyscypliny, historii idei, wymaga współdziałania historyków idei z filozofami politycznymi i filozofami prawa.

Starałem się pokazać, że współczesna republikańska filozofia polityczna bardzo wiele zawdzięcza żmudnym pracom historyków idei. Przed nami żmudna praca nad wczesnonowożytną republikańską koncepcją prawa dla historyka i dla filozofów prawa zastosowanie tych rekonstrukcji do czasów współczesnych. 